\title{
NOTES
}

\section{EXCESS PROFITS, BORROWED CAPITAL, AND BONDS: LATENT TAX LOOPHOLE*}

THE excess profits tax of 1950, ${ }^{1}$ like that of World War II, 2 places an additional tax on corporations whose profits have increased in the general shift to a mobilized economy. ${ }^{3}$ This tax does not apply until the taxpayer's profits are higher than his "normal" profits." The corporation may elect to compute "normal" profits either by average earnings of past years," or by

* MIahoney Motor Co. v. Commissioner, 192 F.2d 508 (8th Cir. 1951).

1. INT. Rev. Cone $\$ 430$ et seq.

2. Revenue Act of $1940 \$ 710,54$ Star. 975 et seq. (1940). Repealed Nov. 8, 1945, 59 StAT. 568 (1945).

3. "An excess profits tax selects for additional tax those corporations whose profits are higher than they probably would have been in the absence of hostilities and a large military budget." H.R. Rep. No. 3142, 8lst Cong,, 2d Sess. 2 (1950). See also SE:3. REP. No. 2679, 81st Cong., 2d Sess. 2 (1950). The same statement of purpose is found in the 1940 excess profits tax: H.R. Rep. No. 2894, 76th Cong., 3d Sess. 1, 2 (1940).

4. See notes 5, 6 and 7 infra. Congress was determined that rearmament, both in 1940 and 1950, should not create "war millionaires." Since profits could not be traced directly to war or defense contracts, it was thought best to restrict profits to a peacetime, or normal, amount. See H.R. Rep. No. 2894, 76th Cong., 3d Sess. 1 at seq. (1940); SEn. Rep. No. 2679, S1st Cong., 2d Sess. 4, 5 (1950). See also Commissioner v. South Texas Co., 333 U.S. 496, 497 (1947).

5. Int. Rev. Cone $\$ 434$ (a). See Sen. Rep. No. 2679, 81st Cong., 2d Sess. 3 (1950). See also 54 STAT. 976 (1940). Under present law, a taxpayer may calculate his excess profits tax without reference to the "credit" representing normal profits, if his tax is lower by the alternative method. The computations are fairly complicated for taxible years before Jan. 1, 1951; see INT. Rev. CoDE $\S 430$. The taxpayer may pay a 30\%o ta: on excess profits adjusted net income, which is net income (with certain adjustments) minus the excess profits "credit"-(his "normal" earnings); sce Ixt. Rev Cove $\$ 431$. Aiternatively, he may pay a tax equal to the regular tax on excess profits net income (net income, with certain adjustments, but not minus the excess profits credit) subtracted from $62 \%$ of excess profits net income, $\S 430$ (a) (2) (A). For taxiable years after Jan. 1, 1951, the alternative tax is $17 \%$ \% of excess profits net income, $\S 430$ (a) (2) (B), and $18 \%$ for years after March 31, 1951.

Generally, however, a firm whose profits are not abnormally high with reference to that firms's "normal" profits, will use the $30 \%$ of excess profits adjusted net income method. For such firms the size of the credit is very important. Firms whose profits are abnormally high, however, will take advantage of alternative methods of computing the tax. Since these deal with "excess profits net income," and not excess profits adjusted net income, no account is taken of the excess profits credit, except that firms must calculate their tax by both methods in order to ascertain which results in the lower tax. For detailed discussion with formulae, see CCH Excrss Psofirs TAX REP. IIT 51,12851,134 ( $3 \mathrm{~d}$ ed.).

6. Under the World War II law, 1936 through 1939 were the base years, and 95\%० of this base period's average income was included in the credit. 54 SтAт. 980 (1940), 
a percentage return on invested capital. 7 The "invested capital" tax base includes not only equity capital ${ }^{8}$ but a percentage of borrowed capital as well. And $12 \%$ of new "invested capital" may be added to the average earnings base under present law. ${ }^{9}$ Under the World War II law, "invested capital" included only $50 \%$ of borrowed capital. ${ }^{10}$ However, the 1950 excess profits tax raised the amount to $75 \%$ as a result of congressional feeling that borrowed capital must yield a "normal" return before excess profits taxes "to provide incentive for a corporation to expand."11

note 2 supra. The present base period is 1946 to 1950, INT. REv. CoDE $\S 435$ (b). 83\% of the average earnings for this period comprise the credit, $\S 435$ (a) (1) (A). This method is most frequently used. The alternative method of computing the $30 \%$ tax (see note 5 , supra, for other tax rates that may be used instead of the $30 \%$ rate), is a percentagc of invested capital. This is used by firms whose earnings during the base period were unduly low. "Your committee conceives of this tax as primarily a tax on increased profits due to the outbreak of hostilities. . . . This accounts for the primary emphasis upon the average earnings base. However, it is believed that a minimum rate of return, free of excess profits tax, should be allowed taxpayers who happened to have poor earning experience in the base period. Therefore, taxpayers are offered an invested capital credit as an alternative. . ." SEN. Rep. No. 2679, 81st Cong., 2d Sess. 3 (1950).

7. "[T] he excess profits credit for any taxable year computed under this section shall be ... the invested capital credit computed under section $437 . .$. " INT. Rev. Cont $\$ 436$ (a). The rate of return permitted before the tax is applied varies with the total capital investment, e.g. the return on investment over 10 million dollars is $8 \%$; the untaxed return on investment under 5 million dollars is $12 \%$. $\$ 437$ (a). Under the World War II law, the maximum was $8 \%$. This was subsequently lowered as the war progressed, see 58 Stat. 55 (1944).

8. INT. REv. CODE $\S 437$ (b) (2). This is restricted, however, to equity capital "held ... in good faith for the purposes of the business." $\$ 437$ (c). Congress placed the same limitation on equity capital as on borrowed capital, see note 16 infra. Cf. "The purpose of this limitation is to disallow ... those assets which are not required in the business and which have the principal effect of reducing excess profits tax." Conference Report, Statement of the Managers on the Part of the House, U.S. CopE CoNG. Strvv, 81 st Cong., $2 d$ Sess. 4167 (1950). No cases have arisen on this limitation on inclusion of equity capital in the credit.

9. INT. Rev. CODE § 435(g), § 435(a) (1) (C).

10. 54 Stat. 985 (1940), note 2 supra.

11. "The adjusted invested capital for any taxable year ... shall [include] . . . 75 per centum of the average borrowed capital for the taxable year computed under section 439 (a)"; INT. REv. CoDE $\S 437$ (b) (2). Before passage of the 1950 law, the House and Senate differed over inclusion of borrowed capital. The untaxed return on borrowed funds favored by the House was small, 133\% of the interest paid on the borrowing. See H.R. REP. No. 3142, 81st Cong., 2d Sess. 7 (1950), and tables 2, 3, $i d$. at 8 . The Senate bill included all borrowed capital in invested capital, thus treating it the same as equity capital. SEN. REp. No. 2679, 81st Cong., 2d Sess. 8 (1950). In the final bill the Senate view substantially prevailed, except that $75 \%$, instead of $100 \%$ of borrowed capital was included in the tax base. "The rate of return allowed borrowed capital under the House bill ... will provide little incentive for a corporation to cxpand." SEN. ReP. No. 2679, 81st Cong., 2d Sess. 8 (1950). See 96 CoNG. Rec. 16808 (1950). 
Since only net profits which exceed some fixed percentage of invested capital are taxed, ${ }^{12}$ an increase in invested capital not resulting in greater profits automatically reduces excess profits taxes. But if all new capital could be included in the invested capital tax base, corporations might acquire capital solely to avoid excess profits taxes. And the easiest way to increase invested capital for a definite, limited period to save taxes is through additions to borrowed capital. ${ }^{13}$

The law early attempted to block this result. Though the World War II excess profits tax statute contained no limitations, ${ }^{14}$ a Treasury Regulation restricted borrowed capital includible in the tax base to bona fide indebtedness "incurred for business reasons." Capital borrowed "merely to increase the excess profits credit" was not to be included.15 And the 1950 excess profits tax incorporated the regulation into the statute, requiring that indebtedness be "incurred in good faith for the purposes of the business."18 But borrowing by itself does not assure the taxpayer significant net gain. Interest costs of borrowing offset most of the tax advantage. ${ }^{17}$ Corporations seeking sub-

12. INT. REv. CODE $\S 430$ (a), $\S 431$, and $\S 437$.

13. Though the possibility exists that corporations would issue additional stock: solely to increase invested capital, such a transaction seems unlikely. No cases have been reported. Permanent ownership accompanying stock, possible control problems, the diffeulty of providing a fixed maturity date and the inconvenience and expense involved probably account for the absence of cases. See note $S$ supra.

14. The 1940 act simply defined borrowed capital as "The amount of the outstanding indebtedness (not including interest ... o) of the taxpayer which is evidenced by a bond, note, bill of exchange, debenture, certificate of indebtedness, mortgage, or deed of trust." 54 Stat. 984 (1940), note 2 supra.

15. The Treasury Department defined the meaning of "indebtedness" in U.S. Treas. Reg. 112, $\$ 35.719-1$. "In order for any indebtedness to be included in borrowed capital it must be bona fide. It must be one incurred for business reasons and not merely to increase the excess profits credit." This regulation is substantially in effect at the present time, U.S. Treas. Reg. 130, \& 40.439-1 (1950). The validity of regulation 112 was attacked, but upheld by the Eighth Circuit; Hart-Bartlett-Sturtevant Grain Co. v. Commissioner, 182 F.2d 153, 158 ( 8 th Cir. 1950).

16. INT. REv. Code $\& 439$ (b) (1). Congress incorporated the World War II Treasury Regulation, Treas. Reg. 112, § 35.719-1 (1942), into the statute. For a brief

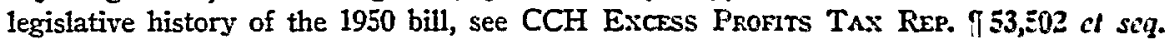
(3d ed.). Congress was concerned over the possible inclusion in invested capital of funds borrowed for insufficient business reasons. "Your committee has also added a provision which excludes from invested capital the assets which are not held in good faith for the purposes of the business. The purpose of this limitation is to disallow in computing invested capital those assets which are not required in the business and which have the principal effect of reducing excess profits tax." SEN. REP. No. 2679, 81st Cong., 2d Sess. 9 (1950). For an expression of similar fears in the debates on the 1940 measure, see remarks of Rep. Lewis in S6 CoNG. REC. 11254 (1940).

17. Contrary to belief prevailing in Congress when the 1950 tax was discussed, very little saving is effected by borrowing funds and holding them, even for firms using the $30 \%$ tax. E.g. $\$ 100,000$ borrowed at $4 \%$ will yield a total saving of only $\$ 880$, since the $\$ 4,000$ interest cost must be deducted from the amount of the reduction in the excess 
stantial gain without risking funds in their own business enterprise, however, could place borrowed capital in either government bonds, savings banks or gilt edge corporate issues. Income from these investments then offsets the cost of the loan, and the amount of the tax reduction becomes net gain. ${ }^{18}$ Thus far, the Commissioner apparently has attempted to exclude from invested capital only indebtedness subsequently invested in government bonds. ${ }^{10}$ Consequently, most litigation has dealt with the question of whether borrowed capital used to purchase government bonds serves a sufficient business purpose to warrant inclusion in the taxpayer's invested capital tax base. ${ }^{20}$

Three factual situations have confronted the courts. In the first, a taxpayer not in the investment business borrowed in order to purchase government bonds, expecting no direct profit either from resale at enhanced market price or from a return on the bonds greater than the interest cost of the loan. In that case, the courts excluded the borrowed capital from invested capital because of the taxpayer's insufficient business purpose. ${ }^{21}$ In the second, a firm engaged in the investment business borrowed to buy government bonds, realizing profit

profits tax. Other factors, though small, must be taken into account. Interest paid for the loan is deductible as an expense, and interest income from the bonds must be included in gross income. See discussion on CCH Excess Profits TAX Rep. If 53,535 ( $3 \mathrm{~d}$ ed.). For firms using the other method, note 5 supra, there is net loss, since the borrowing has no effect on the tax. See also Rudick, Tax Oricntation Under EPT 111, 6 TAX L. Rev. 337 et seq. (1950-51) for detailed discussion.

18. CCH Excess Profits Tax Rep. If 53,535 ( $3 \mathrm{~d}$ ed.). If the funds can be reinvested at a rate approximately equal to the cost of the original borrowing, thus cancelling out the interest cost, the tax saving to firms using the 30\% method is about $\$ 2,700$ for each $\$ 100,000$ of borrowed capital. At the current rates, yield from government bonds, $2.75 \%$ on the $2 \frac{1}{2} \%$ issue due $1965-70$, will not quite equal the lowest commercial rates, about 3\% per year. See Financial World, Jan. 9, 1952 p. 3. See also current yields from government bonds, X.Y. Times, Feb. 16, 1952, p. 22 col. 4. 5. The difference of $.25 \%$ between the cost of the loan and the income from the bonds, reduces slightily net gain from the transaction. Rates in N.Y. Savings Banks are now $2 \% \% \%$. For corporate bond yields, see notes 65,66 infra.

19. Perhaps this is because government bonds, offering minimal risk, present the strongest case for exclusion. A fortiori, if re-investment in government bonds werc sanctioned for excess profits purposes, other re-investment would be inclucled in the $\operatorname{tax}$ base.

20. Hart-Bartlett-Sturtevant Grain Co. v. Commissioner, 182 F.2d 153 (8th Cir. 1950); Globe Mtge. Co., 14 T.C. 192 (1950); Eneloid Co. v. Commissioner, 189 F.2d 230 (3d Cir. 1951), reversing 14 T.C. 1295 (1950); Mahoney Motor Co. v. Commissioner, 192 F.2d 508 (8th Cir. 1951), rcversing 15 T.C. 118 (1950). Cf. West Construction Ca., 7 T.C. 974 (1946); Gould and Eberhardt Inc., 9 T.C. 455 (1947); Player Realty Co, 9 T.C. 215 (1947).

21. Hart-Bartlett-Sturtevant Grain Co. v. Commissioner, 182 F.2d 153 (8th Cir. 1950). Taxpayer, a grain dealer, purchased war bonds with borrowed funds, admitting he had no hope of direct profit. The corporate taxpayer claimed that resultant good will from communities where it purchased grain was a valid business purpose. Hcld: funds could not be included in borrowed invested capital, since they were not working capital, not utilized for the earning of profits, and not subject to the risks of the business. Sco note 32 infra. 
both on the net interest return and on ultimate liquidation of its bondholdings. Here the capital was held to meet the business purpose requirement.2 ${ }^{22}$ But where a firm not in the investment business borrowed to purchase government bonds, and realized similar direct profits, the Tax Court and the Eighth Circuit recently split on the includibility of the borrowed capital in the taspayer's base. ${ }^{23}$

In Mahoney Motor Co. v. Commissioner, taxpayer was a Ford dealer whose corporate charter authorized it to engage in "any lawful business." 2 During the war, the corporation obtained bank loans to purchase large amounts of government bonds, and used the bonds as security for the loans. ${ }^{25}$ Though the declared purpose of the transaction was to secure lines of bank credit for use after the war in financing automobile time sales, ${ }^{20}$ the taxpayer in fact never utilized these credit lines. ${ }^{27}$ Shortly after repeal of the World War II excess profits tax, and prior to a decline in the bond market, the bonds were sold. ${ }^{23}$

22. Globe Mitge Co., 14 T.C. 192 (1950). This case was distinguished from the Hart case, note 14 supra. Realization of direct profit, the fact that the bonds vere not sold until some time after the tax, taxpayer's need to maintain "lines of credit," and a long study of market conditions made by taxpayer prior to the transactions were cited in support of the distinction.

23. Mahoney Motor Co., 15 T.C. 118 (1950), re'd. 192 F.2d 508 (8th Cir. 1951 ). See also Vernon \& Molloy, Borroaied Capital for Exiess Profits Tax Purposes, 6 Tax: L. REv. 379 (1951), (written, however, before Emeloid v. Commissioner, 189 F.2d 230 (3d Cir. 1951) and Mahoney Motor Co. v. Commissioner, 192 F.2d 508 (8th Cir. 1951) ).

24. "Its articles of incorporation authorized it, in addition to conducting a general automobile business, to carry on, in the discretion of the directors . . . from time to time ... any other lawful business, manufacture, or otherwise, to any extent or in any manner not unlawful.'" 192 F.2d 508, 509 (8th Cir. 1951). This is a common provision in corporate charters, since corporations are given the general powers of a natural person. See Stevens, Corporatrons 1019 ct seq. (2d ed. 1949).

25. This possibly secured lower rates of interest. Taxpayer's financial condition was not good at the time of the loans, yet interest rates on the loans were low. 15 T.C. 123 (1950). See also note 52 infra.

26. It is doubtful if borrowing to purchase bonds would affect a bank's subsequent decision to lend. Bank loans are governed by collateral, and the ability of the torrower to pay back. See, however, testimony of bankers called by the Mahoney Co. who testified that borrowing to buy government bonds would be regarded by the bank as "good experience" and "favorable" 15 T.C. 118, 128 (1950).

27. This led the Tax Court to the conclusion that the borrowing was for an insubstantial purpose. 15 T.C. $11 S$ (1950). Compare with substantiality of business purpose under INT. REv. CONE $\$ 102$ (unreasonable accumulation of surplus taxed at penalty rate). KOMA, Inc. v. Commissioner, 189 F.2d 390 (10th Cir. 1951).

28. The Tax Court viewed this as tending to show that the funds had been borrowed merely to increase the excess profits credit. The time at which the bonds were sold was also important in distinguishing Globe Mitge. Co., 14 T.C. 192, 197 (1950) from Hart-Bartlett-Sturtevant Grain Co. v. Commissioner, 182 F.2d 153 (8th Cir. 1950). The fact that the bonds were sold just before a market decline influenced the Eighth Circuit to find that the sale was made to avoid loss, rather than to respond to excess profits tax repeal. Mahoney Motor Co. v. Commissioner, 192 F.2d 508, 510 (Sth Cir. 1951). 
The taxpayer profited doubly from the transaction: the income from the bonds exceeded the interest cost of the loans; and profit was also realized on liquidation at a higher market price. ${ }^{29}$ The taxpayer included the borrowed capital in its excess profits invested capital base, considerably reducing its excess profits taxes. ${ }^{30}$

The Tax Court upheld the Commissioner's exclusion of the borrowed capital from the taxpayer's invested capital base. ${ }^{31}$ In doing so, it employed tests from a prior Eighth Circuit decision: that to qualify as capital borrowed for a business purpose, indebtedness had to be part of "working capital . . . utilized for the earnings of profits ... subject to the risk of [the] business." The Tax Court held the borrowing not to be working capital subject to the risks of the business because employed in a "purely collateral" undertaking

29. The total profit (interest saving plus appreciation of the bonds during the period held) was $\$ 22,351.64$. Id. at 509 . The fact that the interest on the loans (between $11 / 2$ and $1 \%$ ) was lower than the interest income from the bonds is explained by the peculiar situation existing during the war. See, e.g. Business Week, July 28,1945 p. 80 . See also note 57 infra.

30. The borrowing reduced the firm's excess profits tax by $\$ 8,377$ in 1944, and $\$ 11,319$ in 1945 . Petitioner's excess profits tax for 1943 , the year prior to the borrowing, was $\$ 22,717.18$. 15 T.C. 118,120 (1950).

31. 15 T.C. 118 (1950).

32. Hart-Bartlett-Sturtevant Grain Co. v. Commissioner, 182 F.2d 153, 158 (1950). Risk was originally the criterion by which business purpose was judged. In the carly cases involving "evidence of debt" under the World War II law, note 2 supra, dicta referred to the type of borrowing intended to be included in the tax base. Sec West Construction Co., 7 T.C. 974, 978 (1946): "[W] hat was intended [by $§ 719$ supra, note 2] was an investment as to which the business in question assumes some risk: ... Thus, capital funds placed at the risk of the business might be regarded as entitled to an adequate return. . . . But other items, not ... in the nature of capital employed, were to be excluded." (advance payments made to firm by War Department purstuant to construction of contracts held not evidenced by note or bond etc. and not includible in invested capital). This reasoning was followed in Gould \& Eberhardt Inc., 9 T.C. 455, 462 (1947) (advance of purchase price by the Defense Plant Corp. held not subject to risks of the business and not borrowed invested capital for excess profits purposes).

The Hart case apparently reiterated the earlier notions. However, as tests, the Hart dicta are inadequate. "Working capital" is a meaningless term in this context. Sce Emeloid Co. v. Commissioner, 189 F.2d 230, 234 (3d Cir. 1951), where working capital is taken simply to mean funds at any time available to the firm. In Mahoney Motor Co. v. Commissioner, 192 F.2d 508 (8th Cir. 1951), the risk test is satisfied if the borrowing is "authorized" and "profit-pursuing." Id. at 514. See note 41 infra. And yet, as regards speculative profit, hope of profit is the same as risk, the one dependent on market rise, the other determined by market decline. Since requisite risk is now primarily dependent on hope of profit, the latter stands as the principal test. The difficulty with using a "risk" or possibility of profit test, to determine whether substantial business purpose is present, is that some risk or hope of profit is nearly always found. It obscures the main policy issue: to what extent should borrowed capital, cven if there is risk or hope, of profit, be permitted a return free of excess profits taxcs, if possible profits are small compared to tax savings. The desire to encourage risk is but one factor in the decision, and must be balanced against desires to prevent avoidance of the tax through borrowing. 
of the taxpayer corporation. ${ }^{33}$ Since it considered the bonds not subject to the risks of the antomobile business, requisite business purpose was held lacking. ${ }^{34}$ In this way the Tax Court distinguished Mahoncy from its prior decision where it held similar borrowing by an investnent firm includible in the invested capital base..$^{35}$ Moreover, the court went on to observe that here the ultimate business purpose of the borrowing was insubstantial, since taxpayer after the war never utilized bank credit. ${ }^{30}$

The Eighth Circuit reversed and upset the Tax Court's attempted distinctions. ${ }^{37}$ In the Court of Appeals' view, the statute afforded no basis for a distinction between "primary" and "collateral" business activities-all of a corporation's "profit-pursuing," charter-authorized endeavors were equally within a corporation's business, and funds borrowed for these ends constituted working capital subject to risk. ${ }^{38}$ And since, in addition, direct profit was realized, the business purpose requirement was met. This being so, the court found it unnecessary to evaluate future profit possibilities which the bank credit might have opened to the Mahoney company. ${ }^{39}$ Thus the court in terms did not decide whether indirect benefits, such as lines of credit, could give

33. "The program of borrowing from banks and investing in Government securities here embarked upon by petitioner was a purely collateral undertaking so far as its automobile dealer business was concerned." 15 T.C. 118, 127 (1950).

34. "The borrowings were at no time placed at the risk of the automobile dealer business, but were used to buy Government obligations. . . . It is obvious that this factual situation is considerably different from that in Globe Morfgoge Co., ... where this Court concluded from the facts:

... that the petitioner borrowed the suris here in question . . . subjecting the Ibid. borrowed capital to business risks for profit. ..."

35. Globe Mitge. Co., 14 T.C. 192 (1950); sce note 34 stpra.

36. "We . . regard petitioner's desire to s $t t_{1} b l i c h$ bank credit lines for its business as no more substantial a business reason to justify the inclusion of its large borrowings in borrowed invested capital than was the lesire of the taxpayer in the Hart-Barllet case to obtain local good will for its business." 15 T.C. 118, 128. See note 21 sugro.

37. 192 F.2d 508 (Sth Cir. 1951).

38. "Elementarily, in natural or commercial or legal concept, all of a corporation's authorized, profit-pursuing endearors are within its 'business'.... [MI]oney needed and directly employed to carry on any proper profit-making operation or activity of a commercial corporation is in normal concept working capital in the business and subject to business hazard." Id. at 514, 515 .

39. "[T]he Tax Court [gave] consideration also to whether the attempt of the taxpayer ... to establish bank credit ... constituted 'business reasons' and ... appraised this ground as not being sufficiently substantial. . . Whether it is at all possible for borrowings made for purposes other than direct use in immediate-profit activity to have substantiality as to ... [be] 'for business reasons' it is not necessary . . . for us to consider." Id. at 515. Thus once the transaction is authorized, and properly profitpursuing, the Tax Court apparently cannot inquire further. This is, hov:ever, possibly limited to cases where no finding of bad faith has been made by the Tax Court. See $i d$. at 514, n.7. See also notes 41,42 infra. 
substantiality to business purpose where hope of immediate profits was absent. ${ }^{40}$ Moreover, the court noted the requirement that funds be borrowed in "good faith" and not "merely to increase the excess profits credit" still remained as a check upon inclusion of borrowed capital. ${ }^{41}$ And it implied that presence of the requisite business purpose supported inclusion of borrowed capital in the excess profits tax base only in the absence of a Tax Court finding of bad faith. ${ }^{42}$

The Eighth Circuit soundly riddled the Tax Court's unrealistic criteria. Government bonds are subject to identical market fluctuations, regardless of the bondholder's business. ${ }^{43}$ And if government bonds offered a sufficient risk to constitute invested capital for excess profits tax purposes in the hands of an investment firm, ${ }^{44}$ they ought to result in similar tax treatment when held by automobile dealers even though underlying business reasons might be less directly apparent. Actual risks of a decline in the bond market are the same in each case. ${ }^{45}$ Also, borrowings in any form are placed at the risks of the investor's business in the sense that they are subject to claims of his creditors. ${ }^{46}$ Moreover, exclusion from the excess profits credit of capital

40. The Eighth Circuit unaccountably failed to refer to Emeloid Co. v. Commissioner, 189 F.2d 230 (3d Cir. 1951), decided by the Third Circuit several months prior to Mahoney, where borrowing to purchase key man insurance on the life of an officer was held for a business purpose. No direct profit resulted. Moreover, the court obscrved in dicta that borrowing to finance a stock purchase agreement (with no direct profit) would also be for a business purpose. Thus, despite Mahoney's limitation to cases where direct profit could have been made, the Third Circuit has gone further and declared that in some cases indirect profit will satisfy business purpose.

41. "Also, it should be remembered that a simple practical check was provided by the regulation [U.S. Treas. Reg. 112, § 35.719-1 (1942), supra note 15] itself as to all corporate enterprise, old and new alike, engaged in on borrowings made, in that it had to be in good faith and that indebtedness could not constitute 'borrowed capital' for purposes of the statute if it was incurred 'merely to increase the excess profits credit.7" Note 7 of the opinion reads: "The Tax Court did not purport to make any finding here that the taxpayer's venture into the investment field was not undertaken as a good-faith business activity for profit-making purposes or that the indebtedness had been incurred merely to increase excess profits credit." 192 F.2d 508 (8th Cir. 1951). Id. at 514 n.7.

42. Ibid. Thus, even where business purpose has been met, a finding of bad faith, if upheld, would exclude the indebtedness from the excess profits credit. Stuch at finding would be difficult to sustain if direct profit were present. Possibly minutes of a dircetors meeting, or testimony of corporate officers, showing the transaction was entered into for tax purposes primarily, could lead to exclusion on bad faith grounds.

43. "[T]he investment operations of the taxpayer here in government securities could hardly any less have been subject to the possibility of depreciation or loss of market than those in the Globe Mortgage Co. case." Id. at 515.

44. Globe Mtge. Co., 14 T.C. 192 (1950).

45. However, risk is minimal in both cases. See discussion, note 50 infra.

46. Cf. the Third Circuit's interpretation of risk. "[W] hen the insurance procecds are realized on the death of one or both insured, such funds ... will be available, if necded, 
invested in "collateral" ventures would penalize corporate expansion into desirable fields of defense activity.

At the same time, the Eighth Circuit widened a loophole in the excess profits tax. In the Court of Appeals' view, any charter-authorized profit seeking investment apparently qualifies under the business purpose test. But corporate charters are broad or easily amended, ${ }^{4 i}$ and claim of expected profit can always be made. ${ }^{48}$ Thus corporations in all probability may freely include in their excess profits tax base capital borrowed for investment in government bonds. Yet this transaction is obviously an ideal device for tax avoidance. The reinvestment necessary to cancel the interest cost of the loan is accomplished. ${ }^{49}$ And with government bonds the taxpayer enjoys all the benefits of simply holding the money-maximum liquidity and security. ${ }^{\circ 0}$ Thus the taxpayer takes the least possible risk that market declines or other contingencies will reduce his tax advantage. ${ }^{51}$ Moreover, when bonds are pledged as collateral for loans, interest rates may be more favorable than the general

for the payment of creditors of petitioner. Thus, the . . . policies . . are subject, at all times, to risks and hazards of the business." Emeloid Co. v. Commissioner, 189 F.2d 230, 234 (3d Cir. 1951). See also note 40 supra.

47. See note 24 supra.

48. All "profit-pursuing endeavors" are part of a corporation's business (emphasis added), 192 F.2d 508, 514 (Sth Cir. 1951). See note 38 supra. Though the phrase "profitmaking" is used in the same context, id. at 515, reasonable expectation of profits, (profit pursuing), is the only test possible. Otherwise, funds borrowed by corporate officers to finance ventures which later turned out unprofitable, e.g. through a sudden change in consumer buying habits, would be excluded from the credit, even though loss was not probable at the time the transaction was made.

For ways in which hope of profit may be claimed see Rudick, Tax Oricnlations under EPT III, 6 TAX L. REv. 350 (1950-51). The Mahoney decision does not seem to require a showing that profits were in fact made.

49. See note 17 supra.

50. Bonds have liquidity in that they are convertible into money at any time. Security is evidenced by the fact that fluctuations in the government bond market are minimal. Prices are quoted in 32ds of one dollar. See also small degree of fluctuation and low volume of trading, N.Y. Times, Feb. 16, 1952, p. 22, col. 4, 5. For bond yields since 1920 see Federal Reserve Charts on Bank Credit, Moncy Rates, and Business, Sept. 1951, pp. 46-7. Security is further evidenced by the fact that investors have accepted lower yields on government bonds than on any class of security. Ibid. A floor on the price of bonds is set by the fact that the government may be unwilling to pay the high yields caused by low prices, and has in the past used Reserve open marliet operations to keep down the cost of the national debt. The spectacular fight between the Treasury and the Federal Reserve over whether the market should be supported, ending in the decision to withdraw support in Feb. 1951, highlights the concern over the cost of refunding the debt. See, e.g. Business Week, May 4,1946 , p. 19, id. MIarch 10, 1952, p. 132. See also note 62 infra.

51. Occurrences which may impair the value of commercial investment, such as default on bonds, insolvency of a company, or shifts in consumer purchasing patterns, cannot affect government bonds in the sense that payment of the face amount would not be paid on maturity. 
credit standing of the taxpayer would warrant. ${ }^{52}$ The Eighth Circuit thus sanctioned the perfect business transaction: tax gain without corresponding risk of business loss.

In the absence of statutory amendment, courts in some cases might still plug the excess profits tax loophole Mahoney widened. In World War II, lack of other investment areas normally open to private investors, ${ }^{53}$ plus record accumulation of liquid savings, ${ }^{54}$ forced up government bond prices ${ }^{\text {to }}$ with

52. 'At the same time some banks allocate a portion of the 'risk' element to the interest rate rather than allocating it entirely to the margin requirements. Such banks, while of course requiring higher margins for securities other than United States Governments, might also allow a slightly lower interest rate on this latter class of collateral. As a practical matter, we believe the general practice among New York City banks, including our own, is to charge corporate borrowers a somewhat lower rate on loans secured by Governments than on those collateralled by listed securities." Communication to the YaLe LAW JouRNaL from Reginald Russell, Assistant Cashier, Chase National Bank of the City of New York dated March 4, 1952, on file in Yale Law Library. The Mahoney Company, for instance, was able to secure the lowest rates, even though past financial history had not been favorable. 15 T.C. 118 (1950).

53. At the height of the war, the allocation of materials and labor was determined by priority. Non-essential fields, such as new housing, were drastically reduced. Sec, e.g., Chandler \& Wallace, Economic Mobilization and Stabilization, 107 et sel. (1951).

54. Demand deposits in commercial banks rose from 20.9 billion dollars in 1939 to 60.2 billion in 1945. Time deposits rose $181 \%$, reaching 47 billion dollars in 1945 . Federal Reserve Bulletin, July 1949, 794. Cited in CHANDLER \& WALLACE, op. cit. supra note 53 at 189 . See note 57 infra.

55. Banks, other institutions and the public generally were eager for bonds during the war, since the supply of money was rising, and controls made it difficult to spend. As a result, "[a] large part of [bond holdings] were 'forced savings.' They did not represent the free choice of people as between consumption and saving. People werc forced to limit their consumption spendings by the combination of a scarcity of consumption goods and price ceilings. ... Price ceilings ... proved to be a potent method of forcing people to save ... a large part of their swollen money incomes after taxcs." Chandler \& WALLACE, op. cit. stipra note 53, at 188. Investment in governments was further encouraged by the fact that "[t] he dominant objective of the Federal Reserve was to assure that the Treasury would not want for money and that it would not have to pay higher interest rates. . . . The Federal Reserve agreed . . . upon a structure of interest rates, and then stood ready to buy all the Federal obligations that others did not wish to hold at these rates," Id. at 187. During the war, prices of government bonds rose steadily. E.g. $2 \%$ bonds, maturing in 1952-54, were issued at par on Nov. 20, 1944, to open the Sixth War Loan. On the first day the price rose to 100.09 , reached 100.22 after 30 days, and climbed to 102.2 after three months. After six months, the bonds had reached 103.7. Childs, Concerning Government Securities 398 (1946). Because larigc quantities of bonds could be purchased on low margins, the inherent profit possibilities are apparent. Low interest rates for borrowing, note 57 infra, made margin purchase of bonds extremeiy attractive. This practice was discouraged by the Treasury, since bonds bought for speculation would not be held for any length of time. Scc, c.g. Business Week, July 28,1945 , p. 80 . Further, margin buying had an inflationary effect, by creating new bank deposits. To prevent this banks were limited in purchase of bonds, and every effort was made to have bonds purchased instead by private citizens and nonfinancial institutions. CeandLER \& WALLACE, op. cit. supra note 53 at 187. 
corresponding reduction in bond yields. However, banks faced with similar constricted investment outlets and government limitations on subscription to some war loan issues ${ }^{56}$ were willing to place capital with private borrowers at interest rates even lower than government bond yields. ${ }^{57}$ As a result, borrowers seeking to invest in government bonds, aside from tax savings, could look forward to a dual direct profit: profit realized by sale at enhanced market prices of issues bought, ${ }^{5 s}$ and profit resulting from bond yields exceeding the borrowing cost. But these factors do not characterize today's government bond market. Presence of lucrative alternative investment channels, despite voluntary credit restrictions, serves both to depress bond prices, and at the same time keep commercial loan rates above bond yields. ${ }^{\text {co }}$ Banks today are not limited in their purchase of government bond isues, and thus are not likely to lend to private borrowers at interest rates lower than bond yields. Therefore, a court faced with a corporation's current borrowing for purchase of government bonds might well emphasize current depressed conditions in the government bond market and find the borrowing either not for the requisite business purpose, or lacking good faith and undertalien merely for reduction of the excess profits credit. ${ }^{61}$

56. Banks were somewhat limited during the war to the federal bond issues and amounts of issues they were permitted to subscribe to. In the Fifth War Loan, for example, bank holdings of the popular $2 \% / 2 \%$ bonds, maturing $1965-70$, were restricted to $20 \%$ of total bank savings. Further, no bank could subscribe to more than $\$ 400,000$ worth. ChILDS, op. cit. supra, note 55 at 525-8.

57. "[F]iscal and monetary policies were such that the private sectors held greatly increased quantities of liquid assets at the end of the war. Wartime deficit spending coupled with price controls and a scarcity of consumption goods, forced abrormally large amounts of private saving. ... Both individuals and business firms enjoyed great increases [in liquid assets]. ... [F] inancial institutions and other lenders were both able and willing to draw upon their large liquid savings to supply almost unlimited amounts of loan funds to borrowers." ChANDLER \& WaLLicE, op. cit. supra note 53 at 188-9. At the same time, government yields on bonds were attractive, made purposely high to insure sale. But the desire to place bonds in the hands of the publie rather than banks, to avoid creating new deposit currency. limited the banl:s to small amounts of the most attractive offerings. In such a manner, it was possible for the Mahoney Co. to borrow at a lower rate than the yield on government bonds. 15 T.C. 118 (1950).

58. Note 55 supra. Profit was maximized by subscribing to original issues, where price was lowest.

59. For current bond prices, see N.Y. Times, Feb. 16, 1952, p. 22 col. 4, 5. See also Business Week, March 10, 1951, p. 132, and note 50 supra. The postrar period saw general liquidation of bond holdings. Outstanding government bonds of moderate maturity (5-10 yrs.) dropped from 25 billion dollars in 1944 to six billion in 1948. Federal Rcserve Charts on Bank Credit, Money Rates, and Business, Sept. 1951 p. 10. Price was maintained under these conditions by government support of the market; soon after withdrawal of support, the price fell, and is currently at a twenty year low of 96 .

60. Bond yield of $2 \pi / 2 \%$ government bonds is $2.75 \%$. Commercial prime rates are $3 \%$ per year. Financial World, Jan. 9, 1952, p. 3.

61. See notes 41,42 supro. 
Yet this solution is unsatisfactory. A taxpayer could point to the possibility that the Federal Reserve Board will once again support the government bond market, securing profits to those buying bonds at present prices." Moreover, some profit from speculation in government bonds is always possible. ${ }^{63}$ Since, according to the Mahoney case, business purpose is met if the purpose of borrowing is "profit-pursuing," 64 the profit possibilities of the present government bond market, though minimal, might nevertheless qualify under the Mahoney rule. Even were all funds borrowed for government bond purchase flatly excluded from the excess profits tax base, taxpayers could easily obtain similar tax savings through purchase of "gilt edge" corporate or municipal bonds. ${ }^{65}$ And because yields on long-term bonds are usually higher than short-term commercial interest rates, ${ }^{\mathbf{6 6}}$ a direct profit would usually result. While the relatively minor market risks ${ }^{87}$ of this type of investment would not discourage it as a tax reduction device, net interest gain and greater chance of speculative profit clearly satisfy the Mahoney test.

To close all avenues of tax avoidance, Congress should amend the business purpose and good faith criteria of the Code. All capital borrowed for the purchase of bonds might simply be excluded from the excess profits tax base. ${ }^{08}$ But borrowing to buy bonds can take many forms. A corporation, for example, could utilize its surplus cash to invest in bonds while borrowing to expand its plant-thus, in effect, borrowing to purchase bonds. For ally

62. As a result of the current unbalanced budget, the Treasury nay again succecd in establishing a policy of government support of the market. Such a step would enable new issues to be brought out without incurring high interest costs now existing. Holders of bonds, who purchased at current levels, would, however, realize considerable profit from such a step, e.g. bonds now purchased at 96 would then be bought at par, 100, by the Federal Reserve. Consequently, a taxpayer might be able to establish a ground for profit expectation by a showing that he expected renewal of government support.

63. See, e.g. quotations of government bond prices in N.Y. Times, Feb. 16, 1952 p. 22 col. $4,5$.

64. Mahoney Motor Co. v. Commissioner, 192 F.2d 508, 514 (8th Cir. 1951). Sec discussion, note 48 supra.

65. There is admittedly morc risk with corporate bonds that market losses will wipe out all tax gains. Whether such risk would deter firms from borrowing to purchase bonds depends largely on the policies of the individual firm and the type of bond purchased. E.g. bond transactions on the N.Y. Stock Exchange, reported in N.Y. Times, Feb. 16, 1952, p. 22 col. 4, show that Aluminum Co. of America (Alcoa) $31 / 8 \%$ bonds due in 1964 varied only $1 / 4$ of a point during 1951, selling between 1011/4 and 1011/2. Compare Chicago \& Northwestern R.R. $4 \frac{1}{2} \%$ bonds due 1999 , which have ranged between $745 / 4$ and $57 \% / 8$ during the same period.

66. Compare Pennsylvania R.R. $41 / 2 \%$ bonds due 1984 , with the prime commercial rate of $3 \%$. A $11 / 2 \%$ profit could be made by borrowing and then reinvesting, if the market remained the same.

67. Risk varies with the bond purchased. See note 65 supra.

68. This would include borrowing through the issuance of corporate bonds, with the funds then used to purchase government bonds or other corporate bonds. 
exclusion to be effective, indebtedness used in such transactions would also have to be excluded from the tax base. ${ }^{63}$

A less drastic amendment would bar any borrowed capital resulting primarily in tax reduction. The indebtedness could be excluded from the tax base if the principal effect of the borrowing was excess profits tax saving. ${ }^{\text {T0 }}$ Under this test, tax savings would be weighed against profits realized or reasonably expected. ${ }^{71}$ Thus, even though a taxpayer did show actual or expected direct profits, courts could exclude from the tax base borrowings mainly aimed at tax reduction. Again, courts could pierce subterfuge borrowing transactions-examining a corporation's bond portfolio before permitting inclusion in the tax base of borrowings for plant expansion. Neither amendment would in any way affect present tax consequences of corporate borrowing for normal business expansion; capital invested in productive facilities would normally meet all tests. But as to borrowed funds used in bond transactions, immediate congressional action is called for. Otherwise, the excess profits tax for many firms could well exist only as an unpleasant memory of the days before the Malioney case. ${ }^{72}$

69. See INT. REv. CODE $\$ 24(a)(4)$ for provision permitting the commissioner to attack inclusion as an expense of premiums paid for insurance where taxpayer is either directly or indirectly a beneficiary. The following type of statutory amendment to the business purpose requirement would probably be sufficient to enable the commissioner to look through transactions of the type illustrated: "All indebtedness incurred for purchase, directly or indirectly of obligations of the United States, of any state or municipality, or of any corporation, may not be included in the excess profits credit."

70. This would enact in statutory form the statement of congressional purpose behind the business purpose test in the 1950 statute. See note 16 supra. For similar purpose behind the business purpose test for equity capital, see note 8 stipra. Admittedly, exclusion of indebtedness "whose principal effect" is to reduce the tax varies but slightly from exclusion on the grounds of being "merely to increase the excess profits credit," the phrase used by the Regulations. See note 15 supra. The use of "merely" suggests, however, that if any slight profit is present or possible, the borrowing will not be "merely" to increase the tax (emphasis supplied). To avoid such results, the wording should be such that indebtedness whose princifal effect is to reduce the tas will not be included in the excess profits credit.

71. The commissioner and the courts would balance the profit and risk factors against the tax saving gained. The decision would seem to offer no greater difticulties in administration than other concepts in the Code, e.g. "ordinary and necessary" business expenses. INT. REv. CODE $\$ 23$ (a) (1) (A).

72. Large firms will probably not use borrowing for such reinvestment, breause of a desire to maintain favorable public relations. Certain policy reasons suggest that taxpayers pay their allotted share of all taxes: "[T] he distribution of taxes should be such as to promote the maximum cooperation of the public in accepting necessary sacrifices and restraints during the defense period. This means that the public must believe that the tax system spreads the burden fairly. The excess profits tax and the progressive income tax are generally accepted as necessary parts of a fair tax system under current conditions." Council of Economic Annsors, The Econosmics of Natronial. Defense 18 (Fifth Annual Report to the President, 1950). "If any major economic group is able to escape the burden of the tax increases... it then becomes necessary to increase the burdens ... of other ... groups. This is unfair and enlarges the required volume of taxation...." Id. at 17. 